\title{
Those Essex girls: the lives and letters of Lettice Knollys, Penelope Rich, Dorothy Perrott Percy, and Frances Walsingham
}

Book or Report Section

Accepted Version

Ioppolo, G. (2015) Those Essex girls: the lives and letters of Lettice Knollys, Penelope Rich, Dorothy Perrott Percy, and Frances Walsingham. In: The Ashgate Research Companion to the Sidneys, 1500-1700. Ashgate, London, pp. 77-92. ISBN 9781409450382 Available at http://centaur.reading.ac.uk/40815/

It is advisable to refer to the publisher's version if you intend to cite from the work. See Guidance on citing.

Published version at: https://www.ashgate.com/isbn/9781409450382

Publisher: Ashgate

All outputs in CentAUR are protected by Intellectual Property Rights law, including copyright law. Copyright and IPR is retained by the creators or other copyright holders. Terms and conditions for use of this material are defined in 
the End User Agreement.

www.reading.ac.uk/centaur

\section{CentAUR}

Central Archive at the University of Reading

Reading's research outputs online 


\title{
THOSE ESSEX GIRLS: THE LIVES AND LETTERS OF LETTICE KNOLLYS, PENELOPE RICH, DOROTHY PERROTT PERCY AND FRANCES WALSINGHAM
}

\author{
GRACE IOPPOLO
}

She was married at least twice: once scandalously in secret for love, and at least once formally for dynastic allegiance, power and wealth. She incurred the wrath of her monarch for at least one of her marriages and never fully recovered her privileged status at court. She was accused of promiscuity and adultery, and her husband's paternity of her children was questioned in court gossip. She was beautiful, seductive, intelligent and charming, and she manipulated the most important royal officials of the realm, most notably Queen Elizabeth I, William Cecil, Lord Burghley, and Sir Robert Cecil, Earl of Salisbury. She was at the centre of dazzling literature, drama, spectacle and art, as well as political intrigue, and she was probably complicit in the notorious treason of her husband, son or brother. Most remarkably, she insisted that her mind, body and sexuality were her own and not the property of men.

To which of the women of the Essex family, Lettice Knollys, her daughter Penelope, her daughter Dorothy, or her daughter-in-law Frances Walsingham does this description pertain? Remarkably, each of these women fits this description. Each was the maker and beneficiary of political and cultural influence and power, and each suffered royal condemnation and national scandal for choosing to think that she could live her life as she chose, regardless of what a royal patriarchy or matriarchy and peers insisted on. Although many historians and literary critics since the sixteenth century have referred to these women merely in the reflections of their politically powerful fathers, husbands, sons or brothers, each 
woman in fact wielded considerable influence and authority in her own right, especially in ignoring myths about the boundaries of behaviour for early modern aristocratic women.

Ironically, each of these women was a true "Essex girl," which the Oxford English Dictionary calls a "derogatory" and "contemptuous term applied to a type of young woman, supposedly to be found in and around Essex, and variously characterized as unintelligent, promiscuous, and materialistic." This late $20^{\text {th }}$ century slang word, especially the labelling of an Essex girl as "promiscuous," could ironically be applied to these sixteenth century true Essex girls from the family of the Earls of Essex. Lettice, Penelope, Dorothy and Frances were each born into wealth, status, and political power derived from their fathers. But each woman acquired even more from her successive husbands. To begin to understand the female dynastic power they assumed, wielded and only occasionally lost in the age of the Sidneys, we need to begin with its matriarch who worked at great cost for so long to establish this power: Lettice Knollys, Countess of Essex and Countess of Leicester.

\section{Lettice Knollys}

Lettice (1543-1634) was the daughter of Sir Francis Knollys (1514-96), one of Elizabeth I's most loyal courtiers, and his wife Katherine (c.1523-69), who was the daughter of Anne Boleyn's sister Mary Stafford, the mistress of Henry VIII during her first marriage to William Carey and mother of Henry's illegitimate son. ${ }^{1}$ Lettice's political relationship through her father and her blood relationship through her mother to the queen brought her early influence at court. In 1560, Lettice made a successful dynastic first marriage, probably to suit her family, to Sir Walter Devereux, second Viscount Herford and later first Earl of Essex. But

\footnotetext{
${ }^{1}$ For a succinct account of Lettice's life, see Simon Adams, "Dudley, Lettice, Countess of Essex and Countess of Leicester (1543-1634),” ODNB. Many popular history accounts of Lettice are sensational rather than scholarly.
} 
within a few years, and apparently no later than 1565 (Leicester's Commonwealth 267), Lettice seems to have begun a romantic relationship, and probably a sexual affair, with Robert Dudley (c. 1532-88), Earl of Leicester, which apparently intensified after her husband Walter Devereux departed for long periods to lead the queen's troops in Ireland beginning in 1573. According to court gossip, Lettice became pregnant more than once by Leicester during her husband's absence. One of those children, a daughter, was rumoured to have survived and been raised by Lettice's relatives, ${ }^{2}$ although there is no way to prove this claim. Further rumours suggested that some of her surviving four children with Walter Essex were indeed fathered by Leicester, a fear that her husband may have shared, particularly in regards to the true paternity of his heir, Robert (1565-1601).

After Sir Walter's death in Ireland in 1576, Lettice appears to have entered into a clandestine marriage with Leicester, the ceremony for which may have taken place at Leicester's home at Kenilworth and became immediately known, at least to his nephew Sir Philip Sidney (Leicester's Commonwealth 202). However, Lettice's father insisted that to protect her reputation she and Leicester had to have a formal marriage service. On 20 September 1578, two years to the day of her first husband's death, and thus the end of the formal mourning period, she married Leicester again at his London-area home Wanstead House, but without the permission or knowledge of Queen Elizabeth who was away on progress at Loughton, the home of Francis Stonor (Leicester's Commonwealth 202). Due to Lettice's pregnancy, the marriage was finally acknowledged but its validity was contested by Lady Douglass Howard, Baroness Sheffield, who claimed that she had married Leicester in

\footnotetext{
${ }^{2}$ The anonymous author of Leicester's Commonwealth (82), claimed that because Walter Devereux "was coming home from Ireland with intent to revenge himself upon my Lord of Leicester for begetting his wife with child in his absence (the child was a daughter and brought up by the Lady Shandoies, W. Knooles his wife)," Leicester had his friends administer Devereux with "an extreme flux" that killed him.
} 
May 1573 and was the mother of his two legitimate children (Leicester's Commonwealth 269, 86). ${ }^{3}$ The Baroness also claimed that, when she refused to accept Leicester's bribe of $£ 700$ to disclaim the marriage, he attempted to poison her and that for her own "safety" she later married Edward Stafford (Leicester's Commonwealth 270). Leicester denied the Baroness's claims and continued his married life with Lettice, although the couple suffered the tragedy of the early death of their son, the only one of his own children that Leicester acknowledged as a legitimate heir. The author of Leicester's Commonwealth, which attacked Leicester's behaviour in private and at court, was one of many who repeated the scurrilous claim that the boy had suffered from a "falling sickness," commenting that it "well may be a witness of the parents' sin and wickedness and of both their wasted natures in iniquity" (89). Both Leicester and Lettice may also have been chastised for their apparent licentiousness in Edmund Spenser's The Shepheardes Calendar (Mounts 195ff.)

Lettice continued to attempt to control her own life, regardless of her monarch's and her family's objections, because one year after Leicester's death in 1588 she married Sir Charles Blount, who was fifteen years her junior. She thus had moved up from Countess of Essex to Countess of Leicester and then down simply to Lady Blount, suggesting that love, or sexual desire, may have been more important to her than aristocratic standing. But, having been accused of poisoning her first husband Walter Devereux so that she could marry Leicester, as repeatedly stated in such texts as Leicester's Commonwealth and William Camden's Annales, ${ }^{4}$ Lettice was then accused of poisoning her second husband Leicester so

\footnotetext{
${ }^{3}$ As Margaret Hannay has privately pointed out to me, Lady Douglas Howard was a Gamage, the aunt of Barbara Gamage Sidney. So her "illegitimate” sons were cousins on that side as well as Leicester's.

${ }^{4}$ In "Devereux, Walter, first Earl of Essex (1539-1576)," J. J. N. McGurk disputes the idea that Lettice poisoned Walter Devereux, as "the rumour that the earl had been poisoned proved groundless, as attested by the post-mortem examination ordered by Sir Henry Sidney. Sidney's report to Walsingham gives a detailed
} 
that she could marry Blount. Lettice survived such scandalous gossip and seemed remarkably uninterested in placating the wrath that her second and third marriages had provoked in Elizabeth, although her son Robert, second Earl of Essex, attempted several times to reconcile the two women. On one occasion in March 1598 Robert was so angry that Elizabeth had failed to receive Lettice, who had positioned herself in the queen's way with a proffered jewel, that he daringly left his chamber in the castle and "in his night gown went up to the queen the privy way" (Whyte 304). He failed on this and every other occasion to convince Elizabeth once again to formally acknowledge her cousin Lettice. ${ }^{5}$

The scandal of Lettice's third marriage only intensified when Blount was tried and executed in 1601 as a conspirator in the rebellion of Lettice's son Robert Devereux. Although both her husband and her son were executed for a treasonous plot that was planned and managed from Robert's London home, Essex House, where she was a frequent visitor, Lettice seemed not to have been formally implicated or even suspected of being a conspirator. However, Lettice and her daughter Penelope had been shrewd enough to ingratiate themselves for many years with King James VI of Scotland and his wife Queen Anne of Denmark, thereby guaranteeing their protection when the monarchs came to the English throne. But even after 1603, Lettice's life of scandal was still not behind her: she spent years involved in protracted legal battles with Leicester's illegitimate son Robert

description of Essex's last days, and likewise his secretary, Edward Waterhouse, wrote a sad account, printed in William Camden's Annales (as edited by Thomas Hearne, 1717). A manuscript copy of the latter, erroneously attributed to Thomas Churchyard's hand and once belonging to William Cole, the Cambridge antiquary, is now in the British Library (Add MS 5845, fol. 337-49).

${ }^{5}$ For a discussion of the relationship between Essex and Elizabeth see especially Paul E. J. Hammer, The Political Career of Robert Devereux, $2^{\text {nd }}$ Earl of Essex, 1585-1597 and Grace Ioppolo, “"Your Majesties Most Humble Faythfullest and Most Affectionate Seruant': The Earl of Essex Constructs Himself and His Queen in the Hulton Letters." 
Dudley over Essex family estates, which were finally decided in her favour, but not before Lettice was charged with defending the legitimacy of her marriage to Leicester and disproving yet again charges of adultery before and during her years as Countess of Leicester. Her final years were spent in the company of her grandson, Robert, third Earl of Essex, who survived his own sexual scandal during the annulment proceedings of his marriage to Lady Francis Howard, in which he was required through a series of physical tests to prove that he could, in theory, consummate his marriage but in practice had not succeeded in doing so. Lettice outlived most of her children, dying a rich woman, as demonstrated by her still-extant household inventory (BL Additional MS 18985) at the age of ninety-one in 1643. Judging from letters dating from 1626 and 1629, she may have suffered from palsy in the last two decades of her life. ${ }^{6}$

In many ways, Lettice set the standard of the powerful matriarch, female aristocrat and irrepressible woman for her own children and for those in her court circle. Elizabeth reportedly referred to Lettice in the 1580s as a "she-wolf" (Calendar of State Papers, Spanish 1550-86, 3:477), but never punished her with anything other than banishment from her presence. No matter what the political or personal scandal, intrigue, or plot in which Lettice was involved, she survived all attempts to silence or punish her, largely because she pretended, at least, to use discretion and decorum to ignore such attempts. Her sister Lady Anne West seems to have been as judicious, or at least fortunate. At one point she was supposedly overheard telling Lady Anne Askew that "one day she should see her sister, upon whom the queen railed so much (for so it pleased her to term her Majesty's sharp speech) to sit in her place and throne, being much worthier of the same for her qualities and rare virtues than was the other" (Leicester's Commonwealth 128). Judging from the fact that Lettice

\footnotetext{
${ }^{6}$ Her handwriting is notably shaky in these letters: State Papers 16/44/137 and 16/154/82.
} 
continued a cordial friendship with Robert Cecil, who had prosecuted and helped to execute her son Robert and her husband Charles, she must have learned to leave personal grudges and resentments behind her. She appeared expertly to understand that aristocratic women could only wield direct power by seeming to wield it indirectly through men. Perhaps her relationship to Queen Elizabeth through her parents, her second husband and, for several years, her traitorous son Robert protected Lettice from recrimination. Perhaps, more simply, Elizabeth grudgingly respected Lettice's success in manipulating power in a culture that denied woman so much of it. Certainly what Lettice gained through her daring and boldness was worth this sacrifice.

\section{Penelope and Dorothy Devereux}

If Lettice's sexual scandals and intrigue seem remarkable, they pale in comparison to those in the lives of her daughters Penelope and Dorothy and her daughter-in-law Frances. As the daughter of Sir Walter Devereux and later the stepdaughter of Leicester, Penelope (15631607) was certainly not without male power and influence even as a child. She first married, or was forcibly married off to, Lord Robert Rich in 1581, in a union engineered by two of her guardians, the Earl of Huntingdon and Lord Burghley, ${ }^{7}$ and she married second, and illegally, on 26 December 1605, Charles Mountjoy (1563-1606), Duke of Devonshire, her lover for the previous twelve years and father of six of her eleven children. Although King James I approved Rich's suit for divorce from Penelope, the king forbade them afterwards to marry their long-term partners. Both defied James, forcing him to banish them from court, despite Mountjoy's attempts to petition James to recognize the unhappiness of Penelope's first marriage. Her private joy at her marriage to Mountjoy ended in grief however when he died

\footnotetext{
${ }^{7}$ See Henry Huntingdon's letter of 20 March 1580 to Burghley about the match, British Library Lansdowne MS 31 fol. 105 .
} 
on April 3 in the following year, so perhaps the couple's reckless defiance was prompted by their knowledge that Mountjoy did not have long to live. In the end, Penelope did get what she wanted for so very long - the titles of wife to Mountjoy and Countess of Devonshire, the latter title being held for only slightly longer than one year until her death on 7 July 1607. Leicester seemed similarly ambitious in providing a first husband for Penelope's sister Dorothy (1564-1619). He made an attempt to match Dorothy with his nephew Sir Philip Sidney in January 1582, and possibly with King James VI of Scotland (later King James I), the latter attempt purportedly provoking Elizabeth's ire (Freedman 70 and Hammer, "Politics" 53). Yet Dorothy seemed intent on not being forcibly married off to suit dynastic concerns, as her sister had been, and defied convention, control and, her own family and the queen in 1583 by eloping, evidently with Penelope's assistance, ${ }^{8}$ with Sir Thomas Perrott, son of Sir John Perrott, after explicitly being denied permission to do so. As the story was later reported, "that unequal marriage" took place in the chapel at the home of Dorothy's guardian Sir Henry Coke at Broxbourne in Hertfordshire, where "they were married by a strange Minister, whom they had procured, two Men guarding the Church Door with their Swords and Daggers under their Cloaks, as the rest of the Company had, to the Number of five or six." When Reverend Lewis, the local vicar, repeatedly tried to stop the wedding, claiming that the marriage by special licence "without the Banns asking" violated Church law, he was assaulted and told that John Aylmer, the Bishop of London, had provided the licence. After a series of threats, Lewis finally became silent and watched as the wedding proceeded while Sir Henry's servants failed to break down the chapel's doors. Aylmer was later disgraced for his role in the secret wedding, and Dorothy was shunned not only by her new father-in-law but the queen (Strype 327-29 and Freedman 71). Perhaps Coke and Burghley felt that Perrott was a fortune hunter of too low a status who was taking advantage

\footnotetext{
${ }^{8}$ See John Perrott's letter to Penelope, SP 12/161/22.
} 
of a naive Dorothy, but more probably the two men had recognized that she was a commodity to be sold to a much higher bidder.

One of Essex's male biographers Robert Lacey asserted that this disastrous wedding should be blamed on "the inadequacies of Lettice's own relationship with her first husband" and the lack of "warmth or strength of affection" of either of Dorothy's parents, which left her and her brothers and sister "emotional cripples" (23). However, female biographers may see things differently: rather than using a long-outdated Freudian approach to blame Lettice for bad mothering, we can suggest that Dorothy was determined to avoid the types of marriages of convenience that her mother and sister had been forced to accept. As two letters to Burghley demonstrate (see below), although Dorothy was grateful that Thomas had been released from Fleet Prison after the wedding, she continued to defy Burghley after he attempted to annul the marriage. Dorothy similarly tried the patience of her cousin Queen Elizabeth, at one point going to stay at a stately home that was also hosting the queen, who insisted Dorothy stay out of her way and in her room, despite the angry objections of her brother Robert, who blamed his rival Sir Walter Ralegh for inciting the queen against Dorothy, whose presence was taken as a mark of disrespect. As Ralegh had probably planned, the entire visit seems to have devolved into a number of arguments between Robert and Ralegh, and between Robert and Elizabeth, who took the opportunity of further attacking Lettice (Lacey 44; Freedman 73). Finally, Essex forced his sister to pack up and leave in the middle of the night and he followed her shortly afterward.

But Dorothy's defiance did not need to last much longer. By 1594 she had become the mother of four daughters, but her husband was dead and her father-in-law had died in 1592 in political disgrace. Despite inheriting from Perrott's family substantial lands and property, including Syon House, Dorothy had evidently learned her lesson and became acquiescent and obedient, for within a year, and probably for dynastic reasons, she married William Percy 
(1564-1632), who soon became the ninth Earl of Northumberland, later known as the "Wizard Earl" for his interest in alchemy. His later comments to his son on his choice of Dorothy were not flattering: he specifically wanted an heiress who could breed male heirs (Freedman 95). Not surprisingly, the marriage was soon in trouble, and the couple separated in 1599 (see Nicholls, $O D N B$ ), probably because their two sons and heirs had died as infants, and Dorothy had only managed to produce a daughter named Dorothy, who survived, and would later marry Sir Robert Sidney, second Earl of Leicester. Dorothy and William Percy were reconciled after Dorothy's brother Robert told her that she would have to live with the consequences of her choice of husband, although there is no way to tell if she did indeed choose him. Although now Countess of Northumberland, and by 1604 the mother of several more children, including the all-important male heir Algernon, her life would never achieve the domestic happiness of her sister's with Mountjoy, for Percy was implicated in the Gunpowder Plot of 1605 and imprisoned in the Tower of London for life. However he was eventually released in 1621, two years after Dorothy had died. Dorothy had demonstrated herself to be a loyal and evidently loving wife who visited her husband nearly daily, and at least one of their children was conceived during his imprisonment. But perhaps her cordial relationship with her husband from 1605 stemmed from the fact that due to his incarceration, she was able, at last, to run the Northumberland estates in her imprisoned husband's stead and was the Earl in all but name only. Political intrigue finally allowed her to assume the role of a man.

\section{Frances Walsingham}

It would be unfair to suggest that the standard successively set by Lettice, Penelope and Dorothy was one to which Frances Walsingham (1566?-1632) was bound once she became one of the Essex women. In fact, Frances did not seem bound to anything or anyone except 
what she desired. The daughter of Ursula St Barbe (d. 1602) and Sir Francis Walsingham (1532-90), Elizabeth I's spymaster, Frances married first Sir Philip Sidney in 1583, then married second Robert Devereux, second Earl of Essex around 1590, and married third Richard de Burgh, fourth Earl of Clanrickard in 1603. Frances's last marriage to a Catholic and her own conversion to Catholicism further scandalized her at court, from which she finally retired to her third husband's estates in Ireland. Penelope also converted to Catholicism later in her life, but by that time she had become so infamous for her sexual behaviour that her religious conversion seemed trifling in comparison.

Unlike Penelope, Frances did not need a divorce to enter into second or third marriages, for Sidney, her first husband, died nobly after being wounded in the thigh in battle at Zutphen in 1586. Essex, her second husband, died ignobly in 1601 by the executioner's axe after failing in his rebellion against Queen Elizabeth. In a sense, Frances lost her first husband as recklessly as her second, for Sidney received his fatal wound only because he had failed to cover his legs with armour. Through Sidney and Essex, Penelope and Frances shared at least three psychologically complicated and somewhat incestuous bonds. First, if Penelope indeed had been Sidney's mistress before his marriage to Frances, and not just his poetic muse "Stella" in Astrophil and Stella, Penelope and Frances physically shared the body of the same man, Sidney. Second, as Penelope was the very dominant and controlling sister of Essex, Penelope and Frances came to share, emotionally, the mind and heart of another man, Essex. Third, as Essex allowed Penelope and Mountjoy to live openly and shamelessly as lovers, long before their illegal marriage, at the homes he shared with Frances, the bond between Penelope and Frances came to be not only sexually promiscuous but voyeuristic and illicit. While Lettice and Dorothy used their voices to claim and exert power as daughters, sisters, wives, mothers, aristocrats, Penelope and Frances most directly serve as synergistic symbols of the intellectual authority of women and how that authority was portrayed by and 
through men. Thus these two women offer the most persuasive, successful, and underappreciated range of representations of early modern women as peers not only to Elizabeth but to the men who controlled her court, culture, and kingdom.

It is mainly through the sexual lives, words, and actions of Sir Philip Sidney and Robert, second Earl of Essex that most scholars have represented Penelope. Scholars have not bothered to represent Frances at all. The only information available about Frances thus far has come through discussion of her father and first two husbands. Lytton Strachey naively stated in 1928 that

[a] shrouded figure, moving dubiously on that brilliantly lighted stage, Frances Walsingham remains utterly unknown to us. We can only guess, according to our fancy, at some rare beauty, some sovereign charm — and at one thing more: a superabundant vitality. For, two years later, the widow of Sidney and Essex was married for the third time - to the Earl of Clanricarde. And so she vanishes. (270) Biographical information about Penelope is much more readily available; during her lifetime, she was commonly known as "an Harlot, Adulteress, Concubine and Whore," due to her relationship with Mountjoy, and King James described her as "a fair woman with a black soul" (Freedman 179, 168). Her feckless brother Robert had called her an emasculating shrew, claiming at his 1601 trial, "[she] did continually urge me on with telling me how all my friends and followers thought me a coward, \& that I had lost all my valour" (Goodman 2:17). We can only wonder what Frances made of the ruination of her first and second husbands by the same woman: Penelope. As Frances was at the bedside of the dying Sidney in October 1583, she may have overhead him when he reportedly uttered the words, "There came to my remembrance a vanity wherein I had taken delight, whereof I had not rid myself. It was my Lady Rich. But I rid myself of it, and presently my joy and comfort returned" (Gifford 169). Even if Frances had not actually heard these words or Sidney had not actually 
uttered them, she could not have helped hearing them later reported as truth in various forms of court gossip.

\section{Reading Penelope and Frances through their Letters}

All these anecdotes about Penelope and Frances exist in third-hand accounts by men. There has been very little attention paid to letters in Penelope's own hand, and, apparently, no attention paid to the letters in Frances's own hand. None of Penelope's or Frances's letters appeared in the 1853 standard printed edition of Devereux family letters, ${ }^{9}$ which Strachey had used, so perhaps that was why he declared Frances an unknown figure who vanished into the mists of time. Although far more autograph letters survive from Penelope than from Frances, there are certainly enough for both women (at least thirteen for Frances and twenty-one for Penelope) to understand their lives, words and actions. ${ }^{10}$ These letters do not include scribal copies of Penelope's notorious letter to the queen in 1600 pleading for her brother to be forgiven for his unauthorized return to England from the Irish wars. As I have argued elsewhere, Essex, and not Penelope, almost certainly wrote that letter to the queen, a belief that Elizabeth and Sir Robert Cecil, her principal secretary, also apparently shared (Ioppolo, "I desire" 299-325). Rather than relying on that letter to the queen to understand Penelope, we can let her and Frances use their own voices in their autograph letters to represent themselves not merely as objectified women, notorious only for the sexual and dynastic use

\footnotetext{
${ }^{9}$ Walter Devereux, editor of Lives and Letters of the Devereux, includes letters from the queen and other important women of the period but reduces mention of Rich to biographical information involving her brother and other male relatives.

${ }^{10}$ The majority of the autograph letters of Penelope and Frances are among the Cecil family papers at Hatfield House. Other letters in Rich's hand are in the Anthony Bacon papers at Lambeth Palace, in various collections at the British Library, and among State Papers at The National Archives, the Bodleian Library, and at least one is in a continental library.
} 
of their bodies (especially evidenced by their multiple pregnancies), but as commanding and powerful aristocrats, known for the political use of their minds.

There is certainly much more known, or perhaps mis-known, about Penelope than Frances. No poems or other literary works attributed to Penelope are extant, although she may have been involved in some way as author or co-author of works written by the Sidney Circle (Lamb 15). Well educated and intellectually sophisticated, she was the patron of poets, translators and musicians (Duncan-Jones, Sir Philip Sidney 246). ${ }^{11}$ Two letters about her can offer two contemporary views of her: the first letter is from the third man that she and Frances came, figuratively, to share, Robert Cecil, and the second letter is from Lord Mountjoy.

In the first letter, from 1600, Cecil discusses with Thomas Sackville, Lord Buckhurst, the investigation into Penelope's letter to the queen, which had been printed without permission. Cecil chastises Buckhurst (a cousin of Penelope, as was the queen) for failing to extract the truth from Penelope during an interrogation. Cecil claims that Penelope has "shewed a proud disposition \& not much better then a plain contempt of her Majesty and yourselfe that was used in the Cause." According to Cecil, the queen was shocked that Penelope "being a Lady to whom it did not appertain so to meddle in such matters, would be so bold to write in such a style to her, especially when the best interpretations which Penelope doth make can not free her from stomach \& presumption when she writ" (Cecil Papers 181/62). Cecil peevishly notes that the queen has obeyed Penelope's request to read and then burn a private letter of apology before he or anyone else could read it. As Cecil's

\footnotetext{
${ }^{11}$ Duncan-Jones offers a number of important readings of Rich's abilities in several articles and in introductions to various editions of Sidney's work, as does Woudhuysen in Sir Philip Sidney and the Circulation of Manuscripts.
} 
letter is heavily revised, it seems that he took particular care in choosing his words here, perhaps to disguise his own anger.

The Queen soon forgave Penelope for her pride, meddling, "stomach and presumption" for this potentially treasonous episode and for another such episode in 1601, when she was arrested as a co-conspirator in her brother's rebellion and placed under the charge of Henry Sackford, Keeper of the Privy Purse. Penelope was eventually released without further charge, ${ }^{12}$ perhaps in deference to her relationship with Mountjoy, who had more obediently replaced her brother as successful leader of the army in Ireland. In his letter to King James in 1606 and his "Discourse in defense of his Marriage with the Lady Rich," Mountjoy claimed that Penelope, as "[a] Lady of great Birth and virtue being in the power of her frends, was by them married against her will unto Lord Rich, one against whom she did protest at the very solemnity, and ever after; between whom from the first day there ensued continual Discord.” Mountjoy adds that “[i]nstead of a Comforter Rich did study in all things to torment her ... After Rich had not for the space of twelve years enjoyed her he did by persuasions and threatnings move her to consent unto a Divorce and to confess a fault with a nameless stranger" in order to secure a divorce (BL Lansdowne MS 885 fol. 86). ${ }^{13}$ Of course, Mountjoy does not admit his part in Penelope's adultery during those twelve years that was so bold that the six illegitimate children he had by Penelope all had the surname of Rich, and two sons, Mountjoy Rich and Charles Rich, had names that continuously advertised Rich's cuckoldry.

\footnotetext{
${ }^{12}$ See for example Hatfield House Cecil Papers 43/30 (in HMC Salisbury 11:44), in which Captain Thomas Lee includes "La. Rich" in a list of 12 February 1601 of conspirators. Her arrest is also documented in various 1601 State Papers at the National Archives.

${ }^{13}$ Other copies of this text are extant in manuscript.
} 
So, was Penelope "virtuous" and abused by the loathsome Lord Rich as Mountjoy claimed, or "proud," disobedient, and presumptuous, as the queen claimed? If neither speaks about Penelope without prejudice, we can listen to Penelope speaks for herself. In her letters, written as is usual with women of this age, in an Italic, or more properly "Roman" hand, she speaks without pride but with some presumption and at least some affection for Lord Rich. In the late 1590s she solicited help at court on Rich's behalf to resolve a financial crisis. As she explained to the Earl of Southampton, "the cause of Rich's earnest desire to have me come up is, his being so persecuted for his land, as he is in fear to lose the greatest part he hath, this next term who would have me a solicitor to bear part of his troubles, and is much discontented with my staying away so long" (Cecil Papers 101/25; see Plate \#). The unusually indulgent Rich surely had a right to reclaim her on occasion. She nursed Rich through at least one serious illness and, in fact, mentions him without rancour throughout her letters, mostly dating from 1588 to 1605 .

Penelope presents herself as an affectionate and loyal friend, and indeed a solicitor on behalf of those facing penury or prison, and a truly gracious benefactress. For example in December 1595 she refused to allow possible exposure to measles to stop her from attending the baptism of a godson, Robert Sidney, later second Earl of Leicester, who would eventually marry her niece Dorothy (Whyte 103-04). This letter from July 1596 to Cecil is typical of Penelope's self-representation:

Worthy Sir Roberte, the oblygation you haue tyed me in, by your Noble and Kinde frendship, doth increase so much, as though I knowe not how to aquit my selfe, of so greate a dett, yet my affection to honor, and estime you euer, shall be as assured vnto you, as your fauours hath bine to me, who desires to merit them. (Cecil Papers 43/30) 
Penelope ensured that each of her letters took up only one page, even if this required her to write circularly around the margins when she ran out of room. Even when writing on a bifolium, which provides four pages, with the fourth page available for the address, she does not venture farther than one page. It appears that she did this to represent herself as one single, visual image, as in a painting or portrait. King James, for one, commended her fineness of wit and her inventive and "well" writings (Cecil Papers 18/50). ${ }^{14}$ However, her solipsism in self-representation does not support William Ringler's still-influential 1962 assertion that "we are left partly admiring her courage, partly deprecating her departure from the moral standards of the day." ${ }^{\prime 15}$ For Ringler, Penelope only exists in relation to Sidney, not in her own right; whether his departure from moral standards was less remarkable than hers is not easy to ascertain.

Penelope did use seduction in her life and in her letters. When Edward, Earl of Bedford confessed on 9 February 1601 to the Privy Council about his part in Essex's rebellion, he claimed that he had had been at home that day with his family at Sunday service, when at 10am,

prayer being ended \& a sermon begun the Lady Riche came into my house, desiring to speak with me speedily ... her lady then telling me the Earl of Essex would speak with me, whereupon I went presently with her in her coach ... About 11 of the clock I came to Essex house where shortly after the Earle of Essex with others of his company drew themselves into secret conference. (Cecil Papers 76/67)

It is not clear whether Penelope dragged Bedford away from his family, his house, and Sunday service at her brother's request or her own, but Bedford was certainly seduced by her

\footnotetext{
${ }^{14}$ For a transcription, see HMC: Salisbury, 3:438.

${ }^{15}$ Commentary: Astrophil and Stella, The Poems of Sir Philip Sidney 443, 446. For a more recent study of Rich's possible involvement in the publication of Sidney's poems, see Woudhuysen.
} 
solicitations to return immediately with her in her own coach to Essex House. At least this is what he claimed when pleading for his life. But perhaps he left so willingly in her coach because he thought her interest in him was personal, not political. Obviously her rhetoric in her speech was as persuasive as in her letters.

Penelope could be openly self-centred: after Frances successfully lobbied Cecil to be allowed access to the ailing Essex during his 1599 imprisonment, Penelope lobbied Cecil for the same privilege, pleading:

$[\mathrm{H}]$ er Majesty told me if she granted me leave, my sister would look for as much, which need be no argument against me, since her Majesty being content to permit that favor but to some few, I may if please her obtain it before others, because I have humbly and earnestly made the first suit. (Cecil Papers 68/10) Penelope does use a form of logical argument here, but her backstabbing of her sister Dorothy suggests a woman who is used to exerting complete control and succeeding at it. Actually, Penelope failed here, for she was not granted access to Essex, unlike her sister-in-law Frances. Perhaps Frances was more selfless or shrewd, or simply considered less dangerous to Elizabeth and Cecil. While Penelope made demands, Frances's letters suggest that she made requests. Not only is Frances's writing style distinctive, so too, evidently, were her writing implements, for in March 1597, Essex told Robert Sidney in a letter, "You know by my hand that this is my wife's pen and ink" (HMC De L'Isle and Dudley 2:242). As a child, Frances, her father Sir Francis Walsingham and her future husband, Sir Philip Sidney, were together in Paris in 1572 during the St Bartholomew's Day massacre of Protestants; what she witnessed with them in looking out of her Paris window is tantalizingly unknown. Nor was that her only encounter with the greatest political debacles of the day: the first mention of her in any letter appears to come in 12 June 1583 from an anonymous correspondent to the imprisoned Mary Queen of Scots. The correspondent urges Mary, 
finally, to make her peace with Elizabeth, and to "bestow some favorable message upon $\mathrm{Mr}$ Secretary Walsingham and Mr Sidney who is shortly to be married to his only daughter and heire" (Cecil Papers 162/105). It is unclear here whether Mary was to bestow this message to Walsingham and Sidney in person or by letter, but in any case, Frances's marriage to Sidney rated the attention of one of the most politically astute and dangerous women of the age.

Sidney probably married Frances at the explicit request of his close friend and mentor Walsingham, and thus, in a sense, Sidney married Francis, not Frances. If, as Katherine Duncan-Jones suggests, Sidney’s sexual interest was primarily homosexual and not heterosexual (240), his choice of bride would always have been political and dynastic, not personal. Nevertheless, the marriage appears to have been happy, but perhaps Sidney learned to love her while she had always loved him. Their still-extant marriage settlement, almost certainly negotiated by her father, allowed her to derive income on rents from Sidney family properties for many years. When Frances rushed to Holland in 1586 to the deathbed of Sidney, she was pregnant but suffered either a miscarriage or a stillbirth shortly afterward. Also at Philip's deathbed was Robert, second Earl of Essex, to whom Philip bequeathed his best sword, and, it was rumoured, Frances herself — or at least, Sidney extracted Essex's promise to protect Frances and her surviving child, Elizabeth. Perhaps in some way Essex thought that by owning Frances's body and mind he could own the soul of his great hero, Sidney.

By 1590 Frances was pregnant by Essex, and their son Robert was born in January 1591. The date on which Frances formally married Essex is not known; however, their secret marriage, probably no later than October 1590, so displeased Queen Elizabeth that she banned Frances, one of her maids in waiting, from court for some time afterward. Thus Frances suffered the same punishment as her mother-in-law Lettice after her marriage to Leicester and Dorothy after her marriage to Thomas Perrott. Frances was pregnant by 
Devereux at least seven more times by late 1600, although only two of these children survived (see Hammer, "Robert Devereux, second Earl of Essex" ODNB). After Essex’s execution, his property was confiscated, leaving Frances and her three "poor orphans," as she called them, penniless. Frances must have been incredibly resilient because she had also been left in a precarious financial state at the death of Sidney and of her father Walsingham, who died bankrupt, due to outstanding debts. Within two years of Robert's death, she married Richard de Burgh, fourth Earl of Clanrickard, although some had gossiped that she had taken up with him even before Essex was cold in the ground. Clanrickard, who had served as courtier to Elizabeth, was rewarded for his, and perhaps his wife's, loyalty to James I by being appointed Governor of Connaught in 1604 . He eventually received the titles of Viscount Tunbridge and Baron of Somerhill, as well as Viscount Galway and Earl of St. Albans, and thus probably provided Frances with the type of stable life and status that she had been denied with her previous two husbands.

Perhaps, having learned secrecy from her spymaster father, Frances knew that subtlety often succeeded where boldness did not. Whether acting in her husband's absences to lobby Cecil to favour or protect a relative, Frances wrote with persuasive, if quiet, passion. Unlike Penelope, Frances was not arrested after Essex's rebellion, even though the two women were both in Essex House that day, although Richard London reported to Cecil on 22 February 1601, three days before Essex's execution:

[A] fellow goeth about the street selling the Ballads, (whereas here is a copy enclosed) \& giveth it out that the Countess of Essex hath made it, which procureth many to buy it. I have sent diverse up \& down ye City to see if they can meet with him I am told that the ballad was made half a year since, \& upon some other occasion. (Cecil Papers 77/1) 
Richard London seems to apologize to Cecil for the accusation that Frances wrote the ballad to defend her condemned husband, as if Frances is not capable of sedition or treason, or at least Cecil will not have it so. The enclosed copy of the ballad must have been confiscated, for it is no longer with London's letter.

Although frequently contemptuous of Essex, Cecil had assisted Frances numerous times, especially, as noted above, enabling her to have access to her husband during his imprisonment. According to one account, Essex spent this time walking in the garden "with his wife, now he, now she, reading one to the other" (Whyte 461). No wonder, Frances had then written to Cecil in one of her most moving letters:

Simple thanks is a slender recompence (good Mr Secretary) for so honorable a kindness as you have done me in procuring her Majesty's gracious consent for my infinitely wished access to my weak lord: yet when they come from a mind truly desirous to deserve it, and from a person that only wants ability to requite it: I doubt not but the same virtue that led you to so charitable a work, will likewise move to you accept in good part so beggarly a tribute. (Cecil Papers 74/79)

Apparently Cecil was moved by her sincerity here: all of his other letters to her have been endorsed by one of his servants by writing "The Countess of Essex to my Master"; however, this letter has been endorsed in his own hand with the comment: "The countess of Essex to me." Evidently Cecil did not wish to share this very private letter by having it docketed by a secretary. As usual, Cecil was also acting expeditiously here, for in November 1599, Frances had turned up at court dressed all in "black of the meanest price," for "all she wore was not valued at $v l$," and begging to be admitted to the queen. But Frances was turned away and told 
to "come no more" (Whyte 378, 382). So Cecil may have been acting at the behest of the queen, and not Frances, in finally allowing her access to Essex. ${ }^{16}$

Cecil came to Frances's aid several more times, particularly after Essex's death, when unlike in 1599, she had actually become the grieving, poor widow in black. In 1601, Frances described in detail to Cecil a ruthless blackmail plot against her. Her servant Daniel had stolen Essex's private letters to her while she was in childbed and was demanding that Frances buy them back or he would distribute forged copies. She did so, pawning her jewels and raising nearly $£ 2000$ in cash. In a series of long pleading letters about Daniel, whom Frances terms "the most perfidious and treacherous wretch that did ever infect the air with breath," Frances pleads for Cecil's intercession in returning her money, so that he can "punish falsehood, encourage truth, relieve the widow, cherish orphans, execute your own decrees and bind me to add somewhat if it be possible to my humble thankfulness for your other honorable favors (Cecil Papers 90/82, 86/123; see Plate \#). What stands out in this series of letters to Cecil, her late husband's chief prosecutor, is not only Frances's moral indignation at Daniel's treachery but her guilt in being punished for her "sins" in relation to Essex's treachery. In fact, she piously quotes Psalms 58:10 in telling Cecil, "I will kiss the rod and bear my burden with humility and patience as becometh me” (Cecil Papers 90/82).

But this was not the first time that Cecil had been privy to Frances's most intimate thoughts, for in 1598 she addressed a letter to Essex in care of Cecil. However, the letter is among the Cecil Papers, suggesting that Cecil did not send it on to Essex in Ireland, as Frances had requested. Frances's excruciatingly private letter to her husband reads in full:

\footnotetext{
${ }^{16}$ Roland Whyte reported in a letter of 3 May 1600 to Sir Robert Sidney that "Lady Essex came this afternoon to see my Lady and her children. Methought to see her clad as she was, was a pitiful spectacle" (474); evidently she continued to demonstrate her penury.
} 
deare lord I did think this bearer would have gone sooner which made me make ready this enclosed letter 4 days ago and since that time I have had the good fortune to receive two letters from you. The first came when I was so sick that I could not speak with Mr Dary which brought it. But the joy which I took in receiving news from you did deliver me out of a fever which held me 3 hours, without any intervening, in great extremity but now I thank my god am free from it but so much weakened by it that I am not able to come of my bed: none that sees me would believe I were with child, for I am less then I was to months ago. Your son Robin is better then ever he was. I fear I shall never receive so great comfort of my other little one unless I quickly mend. I will for this time take my leave being not able to endure long writing. But by the next messenger I hope to write you word of my amendment.

The letter is signed, “your fathful wife, Frances Essex" (Cecil Papers 63/84). Such intimacy did not guarantee Essex's fidelity during his marriage to Frances, for in 1591 he fathered a child by Elizabeth Southwell and in 1596 to 1597 he had an affair with Elizabeth Stanley, Countess of Derby. It was also reported on 12 February 1598 both that "Essex is again fallen in love with his fairest B," possibly Elizabeth Brydges (Hammer, "Robert Devereux") and that "Frances hears of it, or rather suspects it, and is greatly disquieted." If Frances had not yet heard it, this type of irresponsible gossip in a letter to her former brother-in-law Robert Sidney would certainly ensure that she would.

By April 1601, Frances had become so ill with "weak sinews" and a "distempered brain" that she tells Cecil that she could not write out the letter he is reading but had to use a scribe (Cecil Papers 85/139). Although continually plagued with debts, Frances lived long enough to see her children marry into the most prominent families in England. However she did have to bear the exceptionally humiliating gossip about her son Robert's unconsummated marriage to Frances Howard and their subsequent annulment. 


\section{Reading Dorothy and Lettice through their Letters}

If the letters of Penelope and Frances seem extraordinary in their demands that as women they should have the same status as men, the letters of Dorothy are no less commanding, although they lack the charm of those of her sister and her sister-in-law. For example, after Dorothy was reprimanded for her elopement with Perrott in 1583, she writes two letters to Lord Burghley demanding first in September that he be "an erneste meanes vnto the quenes mayesty to voutesafe her gratious letter to Sir Ihone perrott as well for a relese for his promis made to her hyghnes not to do vs any good without her consente.” Dorothy apologizes by stating, "I am lothe to troble your Lordship with my disgracefull fortune but that I haue a great hope of your Lordship tendering my estate, which betterred to be, I desire by your Lordships means but worse then it is it cannot bee" (BL Lansdowne MS 39 fol. 172). But the tone of the letter makes clear that Dorothy is impatient and reckless, and it is no surprise that Burghley's secretary has docketed the letter with the notation, “To intercede with ye Queen on her \& her husbands behalf, who had married, being a Mayd of honour, without ye Queens consent." In a more audacious letter on 24 October, Dorothy admits that she has been "bolde" with Burghley, but nevertheless states, "I know your Lordship is so entertained with great publike causes as myne though in respecte of ther vnhappynes as great as priuate causes may be, yet in so much as it is very harde for any other to haue the feling of our owne esstate as wee haue our selues." Dorothy eventually comes to the point but in a manner and tone that expect deference be paid to her: "I thought it not amis to be my owne solicitor once againe vnto your Lordship besetching our Lordship to haue a fauorable care of me concerning the well payment of my mariage monye" (BL Lansdowne MS 39 fol. 181). She then more strongly asserts, "Whereof the tyme is now to determine that it will pleas your Lordship to geue your good aduise in any way that in reson may be most for myne auayle." Dorothy does 
act in desperation here, citing the debts owed by her husband, and she presumes to address Burghley as her surrogate father, to whom her own father had awarded guardianship upon his death. But unlike her sister Penelope and her sister-in-law Frances, Dorothy dares to presume that familial loyalty, as cousin to Elizabeth and adopted daughter to Burghley, outweighs political status, a belief that often proved dangerous at Elizabeth's court, given the long imprisonment since 1568 and eventual execution in 1587 of her other cousin, Mary Queen of Scots. Unsurprisingly, Dorothy's letters apparently failed to obtain the queen's permission or Burghley's agreement for the payment of her dowry.

Dorothy appears to have lacked the graceful letter-writing skills not only of her sister and sister-in-law but of her mother. As Lettice was the matriarch and role model for these women, it is fitting to end this discussion with a brief look at her own letters. In a 1608 autograph letter to Robert Cecil, by this time the Earl of Salisbury, Lettice begins with this charming sentence: "Noble Lord, I beseech you geue Leue to your poore absente frende to present hur faithfull loue to your honourable memorye, with desyre to hold styll a hyghe place in our fauoure." While the body of this fair copy letter, written in a careful, nearcalligraphic hand, continues in this ingratiating fashion, Lettice finally makes her main point in a cramped marginal note on the left in which she suggests that her grandson Walter Devereux would be a good match for Lord Stallenge's daughter (TNA SP 14/40/3). Whether this bit of business, in which she feels free to indulge, was an afterthought and late addition, or was the main point from the beginning is not clear. However, Lettice has been shrewd enough to de-centre and marginalize her real demand of Cecil in the letter and thereby represent herself as someone on the periphery of power. Her other extant letters include two from 1626 and 1629 (TNA SP 16/44/137 and 16/154/82) to the husbands of her granddaughters, in which she manages to express her affection while insisting on reminding them of her status as matriarch of a large family, which had intermarried into the most 
powerful families of the realm, including the Sidneys and Cecils, and of the estates to which they eventually succeeded. Lettice's scandalous rise and fall as Countess of Leicester, a title she continued to claim even after her third marriage to Sir Charles Blount, was redeemed and legitimated in her granddaughter Dorothy Percy Sidney's eventual succession to the same title. $^{17}$

This study of representative lives and letters of Penelope and Frances and this brief account of Lettice and Dorothy suggest that early modern women in the age of the Sidneys have been unfairly constrained in the boundaries and bonds in which modern scholars have forced them. Although in 1983 Sylvia Freedman produced a fine biography of Penelope subtitled Lady Penelope Rich: An Elizabethan Woman, Freedman's choice of Poor Penelope (originating from a contemporary comment) as the main title exemplifies the way in which even feminist scholars have stripped Penelope and the women of her age of power and authority. In truth, Penelope saw herself as an equal, not a "poor" or unfortunate inferior by virtue of her sex, to her brother and her husbands. Penelope created scandals that would have far reaching implications for poets, dramatists, and pamphleteers. However, Frances unwittingly did the same, on a far wider scale. Due to the marriage of her daughter Honora de Burgh into the Seymour family, Frances came to be the tenth great-grandmother of the current Prince Charles. And because the Seymour family married into the Spencer family, Frances also came to be the tenth great-grandmother of the late Lady Diana, Princess of Wales. Dorothy could also lay claim through her daughter Dorothy Percy Sidney to being

\footnotetext{
${ }^{17}$ On the life of Dorothy Percy Sidney, the daughter of Dorothy and the Earl of Northumberland and the wife of Robert Sidney the younger, see The Correspondence (c. 1626-1659) of Dorothy Percy Sidney, Countess of Leicester, ed. Michael G. Brennan, Noel J. Kinnamon and Margaret P. Hannay (Farnham, Surrey: Ashgate, 2010).
} 
part of the ancestry of Lady Diana. When it comes to spawning scandals with far reaching political, historical and cultural consequences, then, Frances, her two sisters-in-law, and her mother-in-law certainly had what Strachey called a "superabundant vitality." 


\section{Bibliography}

\section{Manuscript Sources}

British Library

Additional Manuscripts 5845, 18985

Lansdowne Manuscripts 31, 39, 885

Hatfield House

Cecil Papers 18/50, 43/30, 63/84, 68/10, 74/79, 76/56, 77/1, 85/139, 86/123, 90/82, $101 / 25,162 / 105,181 / 62$

The National Archives, Kew

State Papers 12/161/22, 16/44/137, 16/154/82.

\section{Primary and Secondary Sources}

Adams Simon. "Dudley, Lettice, Countess of Essex and Countess of Leicester (1543-1634)." $O D N B$.

Calendar of State Papers, Spain (Simancas). Volume 3. 1580-1586. Ed. Martin A. S. Hume. London: Longman, Green, Longman, \& Roberts, 1896.

Camden, William. Rerum Anglicanum et Hibernicarum Annales. Ed. Thomas Hearne. Oxford, 1717.

The Correspondence (c. 1626-1659) of Dorothy Percy Sidney, Countess of Leicester. Ed. 
Michael G. Brennan, Noel J. Kinnamon and Margaret P. Hannay. Farnham, Surrey: Ashgate, 2010.

Devereux, W. B. Lives and Letters of the Devereux, Earls of Essex, in the Reign of Elizabeth, James I., and Charles I. 2 vol. London, 1853.

Duncan-Jones, Katherine. Sir Philip Sidney, Courtier Poet. New Haven: Yale UP, 1991.

Freedman, Sylvia. Poor Penelope: Lady Penelope Rich, an Elizabethan Woman. Abbotsbrook, UK: Kensal Press, 1983.

Gifford, George. “The Manner of Sidney’s Death.” Miscellaneous Prose of Sir Philip Sidney. Ed. Katherine Duncan-Jones and Jan Van Dorsten. Oxford: Clarendon Press, 1973. 161-172.

Goodman, Godfrey. The Court of King James I. Ed. John S. Brewer. 2 vol. London: Richard Bentley, 1839.

Hammer, Paul E. J. The Political Career of Robert Devereux, $2^{\text {nd }}$ Earl of Essex, 1585-1597. Cambridge: Cambridge UP, 1999.

Hammer, Paul E. J. “Devereux, Robert, second Earl of Essex (1565-1601).” ODNB.

Ioppolo, Grace. “'Your Majesties Most Humble Faythfullest and Most Affectionate Seruant': the Earl of Essex Constructs Himself and his Queen in the Hulton Letters." Elizabeth I and the Culture of Writing. Ed. Peter Beal and Grace Ioppolo. London: British Library, 2007. 43-69.

Ioppolo, Grace. “'I desire to be helde in your memory’: Reading Penelope Rich through her letters." The Impact of Feminism in English Renaissance Studies. Ed. Dympna Callaghan. London: Palgrave-Macmillan, 2007. 299-325.

Lacey, Robert. Robert, Earl of Essex: An Elizabethan Icarus. London: Phoenix Press, 1971. Lamb, Mary Ellen. Gender and Authorship in the Sidney Circle. Madison: U of Wisconsin P, 1990. 
Leicester's Commonwealth: The Copy of a Letter Written by a Master of Art of Cambridge (1584) and Related Documents. Ed. D. C. Peck. Athens, Ohio: Ohio UP, 1985.

McGurk, J. J. N. "Devereux, Walter, first Earl of Essex (1539-1576).” ODNB.

Mounts, Charles. "Edmund Spenser and the Countess of Leicester.” English Literary History 19:3 (1952): 191-202.

Nicholls, Mark. "Percy, Henry, ninth Earl of Northumberland (1564-1632)". ODNB.

Historical Manuscripts Commission: Report on the Manuscripts of the Earl of Salisbury. 24 vol. London: His Majesty's Stationery Office, 1883-1976. CONDENSE TO HMSO?

Sidney, Philip. The Poems of Sir Philip Sidney. Ed. William A. Ringler, Jr. Oxford: Clarendon Press, 1962.

Strachey, Lytton. Elizabeth and Essex: A Tragic History. New York, NY: Harcourt, Brace and Company, 1928.

John Strype. The Historical Collection of the Life and Acts of the Right Reverend Father in God John Aylmer. London: W. Boywer, 1701.

Whyte, Rowland. The Letters (1595-1608) of Rowland Whyte. Ed. Michael G. Brennan, Noel J. Kinnamon, and Margaret P. Hannay. Philadelphia, PA: American Philosophical Society, 2013.

Woudhuysen, H. R. Sir Philip Sidney and the Circulation of Manuscripts, 1558-1640. Oxford: Clarendon Press, 1996. 